\title{
Dickeya-sukuiset bakteerit, uusi riesa perunanviljelyssä
}

\author{
Minna Pirhonen ${ }^{1}$, Jaana Laurila ${ }^{2}$ ja Asko Hannukkala ${ }^{3}$ \\ ${ }^{1}$ Soveltavan biologian laitos, PL 27, 00014 Helsingin yliopisto \\ minna.pirhonen@helsinki.fi \\ ${ }^{2}$ Nykyinen osoite: Boreal Kasvinjalostus Oy, Myllytie 10, 31600 Jokioinen \\ jaana.laurila@boreal.fi \\ ${ }^{3}$ MTT, Kasvintuotannon tutkimus, Kasvinsuojelu, R-talo, 31600 Jokioinen \\ asko.hannukkala@mtt.fi
}

\section{Tiivistelmä}

Perunantyvi- ja märkämätä ovat perunalla esiintyviä bakteeritauteja, jotka mädättävät perunan varsien tyviosia sekä perunan mukuloita pellolla ja varastossa. Näitä tauteja aiheuttavien bakteereiden esiintyminen on vakava laatuongelma varsinkin siemenperunan viljelyssä. Taudin esiintyminen heikentää luottamusta kotimaisen siemenen laatuun, lisää paineita ulkomaisen siemenperunan tuontiin ja haittaa suomalaisen siemenperunan vientimahdollisuuksia. Lisäksi mukuloita pilaava märkämätä aiheuttaa vuosittain satojen tuhansien kilojen varastohävikkejä etenkin ruokaperunateollisuudessa. Perunantyvi- ja märkämätää aiheuttavat bakteerit luettiin aiemmin Erwinia-sukuun, mutta niiden taksonomia on uudistettu hiljattain, minkä seurauksena ne jaetaan nykyään kahteen sukuun, Pectobacterium ja Dickeya.

Pectobacterium-sukuisten bakteereiden on tiedetty jo kauan aiheuttavan tautia perunoilla Suomessa. Perunan tautitilanteen on kuitenkin epäilty huonontuneen viime vuosina, minkä vuoksi perunoissa ja jokivesissä esiintyvät bakteerit kartoitettiin vuosina 2004-2007 toteutetussa tutkimuksessa. Tulokset osoittivat, että noin 20\% tyvimädästä johtui todennäköisesti Dickeya-sukuisista bakteereista (edelliseltä nimeltään Erwinia chrysanthemi). Näitä bakteereita on aiemmin pidetty kasvitautien aiheuttajana lämpimissä ja trooppisissa maissa. Ne ovat levinneet viime vuosina huolestuttavasti Keski-Euroopassa ja nyt niitä tavataan siis myös meillä. Tutkimuksen tulokset osoittivat myös, että Suomesta löydetyt bakteerit voitiin jakaa kolmeen ryhmään, joista kahta voitiin eristää sekä jokivesistä että perunoista ja yhtä löydettiin vain jokivesistä Eteläja Länsi-Suomesta. Osa sekä perunoista että jokivesistä eristetyistä kannoista oli hyvin virulentteja. Kaikkien virulenteimmat kannat kuuluivat Dickeya dianthicola -lajiin, joka on karanteenitaudinaiheuttaja koristekasvien kasvihuoneviljelyssä. Monet eristetyt kannat aiheuttivat tyypillisiä tyvimätäoireita mutta myös nekroottisia oireita, jotka eivät muistuttaneet tyypillistä tyvimätää. Tämä saattaa aiheuttaa ongelmia kasvustotarkastuksissa, sillä uudet bakteerit saattavat jäädä niissä havaitsematta. Syyt Dickeya-sukuisten taudinaiheuttajien leviämiseen maahamme eivät ole selvät. Leviäminen saattaa olla seurausta ilmaston lämpenemisestä mutta myös lisääntyneestä maataloustuotteiden tuonnista tai bakteereiden sopeutumisesta kylmempään ilmastoon.

Asiasanat: Erwinia chrysanthemi, Dickeya, peruna, tyvi- ja märkämätä, jokivesi 


\section{Johdanto}

Perunantyvi- ja märkämätä ovat bakteeritauteja, jotka mädättävät perunan varsien tyviosia sekä mukuloita pellolla ja varastossa. Niiden esiintyminen on vakava laatuongelma varsinkin siemenperunan viljelyssä (Pérombelon 2002). Valtaosa sertifioidusta siemenperunasta on puhdasta tyvi- ja märkämädästä, mutta yksittäisissä erissä saattaa bakteereita esiintyä huomattavan paljon. Lisäksi mukuloita pilaava märkämätä aiheuttaa vuosittain satojen tuhansien kilojen varastohävikkejä etenkin ruokaperunateollisuudessa. Tyvi- ja märkämätää aiheuttavat Pectobacterium atrosepticum, P. carotovorum ja Dickeya-suvun bakteerit. Nämä bakteerit tunnettiin aiemmin Erwinia-nimellä (Gardan ym. 2003, Samson ym. 2005). Ainoastaan Pectobacterium-suvun bakteereja on tiedetty esiintyvän Suomessa tähän mennessä.

Euroopan tärkeimmillä perunantuotantoalueilla on 2000-luvulla havaittu tyvi- ja märkämätää aiheuttavassa bakteerilajistossa muutoksia, sillä nykyään esim. Hollannissa jopa yli puolet tyvimätätartunnoista on Dickeya-lajien aiheuttamia. Suomalaisetkin viljelijät ovat raportoineet pahentuneista tyvi- ja märkämätäongelmista ja viljelmistä, joissa lähes kaikki kasvit ovat olleet tyvimätäisiä tai joiden sato on mädäntynyt nopeasti noston jälkeen. Suomessa esiintyvien tyvi- ja märkämätää aiheuttavien lajien yleisyyden ja merkityksen kartoittamiseksi kerättiin vuosien 2004-2005 aikana maa- ja metsätalousministeriön rahoittamassa tutkimuksessa jokivesinäytteitä ja tyvimätäoireisia ja epätavallisia tyvimädänkaltaisia oireita kantavia varsia ja märkämätäisiä mukuloita.

\section{Aineisto ja menetelmät}

Tyvi- ja märkämätää aiheuttavien bakteereiden kartoitusta varten kerättiin tyvimätäisiä varsia Uudeltamaalta, Hämeestä, länsirannikolta ja Pohjois-Pohjanmaalta, ja vesinäytteitä kerättiin Pohjanmaan ja Etelä-Suomen joista. Lisäksi samaan aikaan syksyn ja talven aikana kerättiin märkämätäisiä mukuloita pelloilta ja varastoista.

Tyvi- ja märkämätää aiheuttavat bakteerit tuottavat pektiinia hajottavia entsyymeitä ja pystyvät kasvamaan useimmista kasvitauteja aiheuttavista bakteereista poiketen myös ilman happea. Bakteerien eristys näytteistä tehtiin julkaistun laboratorio-ohjeistuksen mukaisesti maljoilla, jotka sisälsivät pektiiniä (Pérombelon \& van der Wolf, 2002). Näillä maljoilla pektinaasia tuottavat bakteerit hajottavat alustan sisältämän pektiinin ja muodostavat ympärilleen kuopan. Kuopan muodostaneet pesäkkeet kasvatettiin puhdasviljelmiksi ja niiden kyky kasvaa anaerobisesti testattiin. Pektinolyyttisit, anaerobisesti kasvavat bakteerit tunnistettiin PCRtestein käyttäen hyväksi alukkeita, jotka olivat spesifisiä P. atrosepticum -bakteerille (DeBoer \& Ward 1995) tai Dickeya-sukuisille kannoille (Nassar ym. 1996). P. carotovorum -kannat tunnistettiin MTT:llä kehitetyllä PCR-testillä.

Edustava otos (noin $100 \mathrm{kpl}$ ) eristetyistä bakteerikannoista sekvensoitiin ribosomaalista RNA:ta koodaavien geenien väliseltä alueelta (16S-23S rRNA välialue, ITS-alue), ja osa näistä vielä 16S rRNA geenin alueelta. Sekvensointia varten kannoista eristettiin genomista DNA:ta ja välialuetta monistettiin käyttämällä universaaleja alukkeita (1114f ja L1r) julkaistun ohjeen mukaisesti (Fessehaie ym. 2002), ja 16S sekvenssit tilattiin Turun yliopiston Lääketieteellisen mikrobiologian laitoksella (http://www.med.utu.fi/ylab). Bakteerien tunnistus varmistettiin Blast-hauilla ja fylogeneettisia analyysejä varten kantojen välialuesekvenssit rinnastettiin käyttämällä ClustalX-ohjelmaa. Fylogeneettiset puut sekvensseille tehtiin rinnastetuista sekvensseistä käyttämällä MrBayes 3.1.1-ohjelmaa. Puihin otettiin mukaan myös tietokantoihin talletettuja tyyppi- ja referenssikantoja.

Eristettyjen Dickeya-kantojen virulenssia ja virulenssin vaihtelua tutkittiin Bintje-lajikkeella mukulanmädätystestein kasvatuskaapissa ja varsimädätystestein kasvihuoneella. Lisäksi kesällä 2006 joidenkin eristettyjen kantojen kyky aiheuttaa oireita tutkittiin myös kenttäkokein Perunantutkimuslaitoksella Lammilla. 


\section{Tulokset ja tulosten tarkastelu}

Sekä varsi- että mukulanäytteistä löytyi sekä $P$. atrosepticum että $P$. carotovorum -lajeja, mutta myös Euroopassa leviäviä Dickeya-sukuisia bakteereita. Dickeya-bakteereita löytyi n. $20 \%$ tyvimätänäytteistä. Kun edellinen kartoitus 1980-luvulla tehtiin, Dickeya-lajeja ei löytynyt silloin Suomesta. Koska Dickeyasukuisten bakteereiden esiintyminen Suomessa on uusi ilmiö, haluttiin kantoja tutkia tarkemmin (Laurila ym. lähetetty julkaistavaksi).

Suomesta eristetyt Dickeyat voitiin ryhmitellä fylogeneettisissä analyyseissä kolmeksi ryhmäksi. Näistä yksi muistutti ominaisuuksiltaan pahamaineista D. dianthicola -bakteeria, joka on luokiteltu karanteenitaudinaiheuttajaksi koristekasvien kasvihuoneviljelyssä. Sitä ei kuitenkaan lasketa karanteenitaudinaiheuttajaksi muilla kasveilla, joten perunanviljelijälle sen löytymisellä ei ole seurauksia. Kyseistä bakteeria löytyi kolmesta Itä-Uudenmaan joesta ja yhdestä perunanäytteestä, joka oli otettu EU:n suoja-alueelta Oulun seudulta. Muut kaksi ryhmää eivät sopineet nykyiseen Dickeya-luokitteluun ja ovat todennäköisesti vielä tunnistamattomia lajeja. Toinen näistä ryhmistä oli vallitseva Dickeya perunanäytteissä ja edustaa todennäköisesti uutta, Euroopassa nopeasti leviävää uuttaa Dickeya-lajia. Suomesta sitä löytyi perunoista kautta maan. Kolmannen ryhmän kantoja ei löytynyt perunoista, mutta kylläkin monista Etelä- ja Länsi-Suomen joista.

Laboratoriokokeissa todettiin, että vain perunoissa yleisesti tavattavat Dickeya-sukuiset bakteerit aiheuttivat oireita perunan varsissa ja mukuloissa. Kenttäkokeissa molemmat perunoista eristetyt Dickeya-ryhmät aiheuttivat perunalla tyvimätää ja useat kannat laskivat sadon määrää jopa puolella. Eniten oireita aiheuttivat D. dianthicolaa muistuttavat kannat. Ne aiheuttivat usein ensioireena pienten versojen tai lehtien ja lehtiruotien mätänemistä ja varsien nekroosia ja halkeilua. Mädäntyminen näkyi usein varsien yläosissa, mutta halkaistussa varressa voitiin nähdä varren keskustan mustuneen koko varren matkalta. Suurin osa näistä oireista muuttui myöhemmin tyvimädän tapaisiksi oireiksi. Toisen, perunoista useimmiten eristettyjen bakteereiden muodostaman ryhmän aiheuttamat oireet muistuttivat enemmän tyypillistä tyvimätää, mutta myös sillä havaittiin varsien mädäntymistä usein varsinaista varren tyveä ylempänä. Kenttäkoetta havainnoidessa todettiin myös, että Dickeya-kannoilla saastuneet perunat eivät välttämättä haisseet tyypilliseltä tyvimädältä, vaan olivat usein melkein hajuttomia.

Kolmanteen ryhmään kuuluvat, vain jokivesissä esiintyvät bakteerikannat, eivät aiheuttaneet lainkaan oireita perunoilla.

\section{Johtopäätökset}

Kartoitus paljasti, että kaikkia kolmea perunalla tyvi- ja märkämätätautia aiheuttavaa bakteeria tavattiin Suomesta, myös meillä aiemmin tuntemattomia Dickeya-lajeja. Lisäksi yhdestätoista joesta löydettiin bakteerikantoja, ja ne kaikki olivat näitä uusia bakteereita yhtä $P$. carotovorum -kantaa lukuun ottamatta. Perunoista löytyneet Dickeya-sukuiset bakteerit voitiin jakaa kahteen ryhmään, joista yksi on aiemmin Euroopassa perunoilla tautia aiheuttanut $D$. dianthicola ja toinen on todennäköisesti uusi, Euroopassa leviävä perunan taudinaiheuttaja. Lisäksi jokivesistä löytyi perunalle vaarattomia Dickeya-sukuisia bakteereita.

Perunalla tautia aiheuttavat bakteerit ovat todennäköisesti tulleet Suomeen ulkomailta tuodun siemenperunan mukana ja voivat ainakin osittain selittää perunan tautitilanteessa havaittuja muutoksia. Mahdollisesti myös itse bakteerissa on tapahtunut muutoksia, jotka ovat edesauttaneet bakteerien leviämistä maahamme, koska niitä on aikaisemmin pidetty taudinaiheuttajina ainoastaan lämpimissä maissa. Tutkimuksemme osoitti kiistatta, että Dickeya-bakteereita esiintyy Suomessa ja että ne ovat todennäköisesti pysyvä ongelma jatkossakin.

Kenttäkokeemme, jossa tutkimme bakteerikantojen aiheuttamia oireita, antoi merkittävää tietoa Dickeyasukuisten bakteereiden aiheuttamien oireiden ulkonäöstä Suomen oloissa. Siementuojien ja -tuottajien sekä perunanviljelijöiden on oltava tietoisia ja otettava huomioon, että myös uudentyyppisiä Dickeya:n aiheuttamia tyvimätäoireita voi esiintyä perunakasvustoissa. 
Kenttäkokeissa tutkittiin myös jokivesistä eristettyjen Dickeya-kantojen taudinaiheuttamiskykyä. Tutkimus osoitti, että vesistä eristetyt kannat voivat aiheuttaa tyvimätää perunalla. Eniten tautia aiheuttivat $D$. dianthicola -tyyppiset bakteerit, joita löytyi vesinäytteistä jokivesistä Helsingistä itään alueilta, joilla ei ole merkittävää perunantuotantoa. Nämä kannat voivat olla peräisin ruokaperunoista tai vihannesvarastojen tai kasvihuoneiden valumavesistä. Perunalle vaarattomat bakteerit voivat olla peräisin luonnonkasveista tai muilta viljellyiltä kasveilta kuin perunalta. Myös ne ovat myös voineet päätyä vesiin mm. kasvihuoneilta tai kaatopaikoilta. Perunalla tautia aiheuttavien Dickeya-sukuisten, vesissä esiintyvien kantojen merkitys voi olla suuri tartunnanlähteenä, minkä vuoksi jokivesien käyttöä perunapeltojen kasteluvetenä onkin harkittava entistä tarkemmin.

\section{Kirjallisuus}

DeBoer, S. H. \& Ward, L. J. 1995. PCR detection of Erwinia carotovora subsp. atroseptica associated with potato tissue. Phytopathology, 85, 854-858.

Fessehaie, A., De Boer, S. H. \& Levesque, C. A. 2002. Molecular characterization of DNA encoding 16S23S rRNA intergenic spacer regions and 16S rRNA of pectolytic Erwinia species. Canadian Journal of Microbiology, 48, 387-398.

Gardan, L., Gouy, C., Christen, R. \& Samson, R. 2003. Elevation of three subspecies of Pectobacterium carotovorum to species level: Pectobacterium atrosepticum sp nov., Pectobacterium betavasculorum sp nov and Pectobacterium wasabiae sp nov. International Journal of Systematic and Evolutionary Microbiology, 53, 381-391.

Laurila, J., Ahola V., Lehtinen, A., Joutsjoki, T., Hannukkala, A. Rahkonen, A. \& Pirhonen, M. Characterization of Dickeya strains isolated from potato and river water samples in Finland (Lähetetty julkaistavaksi European Journal of Plant Pathology -lehteen).

Nassar, A., Darrasse, A., Lemattre, M., Kotoujansky, A., Dervin, C., Vedel, R. \& Bertheau, Y. 1996. Characterization of Erwinia chrysanthemi by pectinolytic isozyme polymorphism and restriction fragment length polymorphism analysis of PCR-amplified fragments of pel genes. Applied and Environmental Microbiology, 62, 2228-2235.

Pérombelon, M. C. M. 2002. Potato diseases caused by soft rot erwinias: an overview of pathogenesis. Plant Pathology, 51, 1-12.

Pérombelon, M. C. M. \& van der Wolf, J.M. (Eds.) 2002. Methods for the detection and quantification of Erwinia carotovora subsp. atroseptica (Pectobacterium carotovorum subsp. atrosepticum) on potatoes: a laboratory manual. (Invergowrie, Dundee, Scotland: Scottish Crop Research Institute)

Samson, R., Legendre, J. B., Christen, R., Fischer le Saux, M., Achouak, W. \& Gardan, L. 2005. Transfer of Pectobacterium chrysanthemi (Burkholder et al. 1953) Brenner et al. 1973 and Brenneria paradisiaca to the genus Dickeya gen. nov. as Dickeya chrysanthemi comb. nov. and Dickeya paradisiaca comb. nov. and delineation of four novel species, Dickeya dadantii sp. nov., Dickeya dianthicola sp. nov., Dickeya dieffenbachiae sp. nov. and Dickeya zeae sp. nov. International Journal of Systematic and Evolutionary Microbiology, 55, 1415-1427. 